\title{
IN VITRO STUDIES TO EVALUATE SUGAR BEET PULP UNTREATED, SUPPLEMENTED WITH UREA OR TREATED WITH FUNGUS AS A FEED INGREDIENT FOR RUMINANTS
}

\author{
A.A.B. Khaliel, S.T.M. Fahmy, M.T. Sallam, H.A. Hassan and M.A. Abd-El Hakeam \\ Department of Animal production, College of Agriculture, Minia University, Egypt
}

(Received 17/9/2018, accepted 5/11/2018)

SUMMARY

$\mathrm{S}$

ugar beet pulp (SBP) is the by-product of sugar extracting industry from sugar beet. The crude protein content of SBP is $9.16 \% \pm 1.21$. While it 's In-vitro dry matter disappearance (IVDMD) is $58.85 \% \pm 0.76$. Increasing the IVDMD and organic matter disappearance (IVOMD) of SBP either by fungus treatment (Trichoderma Harzianum, T.H) or supplementation with urea $(2 \%)$ to in rich it s N content was the aim of this work. Three in-vitro experiments were conducted in this study. The objective of first experiment (EXP.1) was to determine the IVDMD, IVOMD, In Vitro crude protein disappearance (IVCPD) and in-vitro crud fiber disappearance (IVCFD) of SBP (T1), SBP plus media (2\% urea, 1.5\% ammonium sulphate, $1 \%$ live dry yeast, saccharomyces Cerevisiae and $0.5 \%$ magnesium sulphate as percentages of SBP, T2) and SBP plus media treated with $T . H$ fungi, (T3). The results indicated that treatment with $T$. $H$ (T3) was the most effective in increasing IVDMD, IVOMD, IVCPD and IVCFD above both T1 and T2. The figures were 63.97, 68.30 and $41.24 \%$ for IVDMD, IVOMD and IVCFD of T3. The respective values for T2 were 62.05, 64.70 and 36.45\%, while the values for T1 (the untreated SBP) were 58.85, 62.87 and $34.98 \%$ for IVDMD, IVOMD and IVCFD, respectively. Differences among treatments in each nutrient were significant $(\mathrm{P}<0.01)$. The objective of second experiment (EXP.2) was to find out the best inclusion (level) proportion of USBP in the concentrate feed mixture contained 20\% wheat straw (total mixed ration, TMR), that increase IVDMD and IVOMD. The third experiment (EXP.3) was to find out the best inclusion (level) proportion of SBPT.H. that increase IVDMD and IVOMD. The tested inclusion proportions were $0,20,40,60,80$ and $100 \%$ SBPT. H. The results indicated that $40 \%$ inclusion level showed the best value for IVDMD $71.68 \% \pm 0.65$ and $74.35 \% \pm 0.78$ for IVOMD, while the respective values of $100 \%$ total mixed ration (TMR) were $68.39 \% \pm 0.65$ and $71.86 \% \pm 0.78$ for IVDMD and IVOMD, respectively. The differences were significant $(\mathrm{P}<0.01)$. The results showed that the $40 \%$ inclusion was the best level of USBP in the TMR. The IVDMD was $69.64 \% \pm 0.59$, while the IVOMD was $72.68 \%$ \pm 0.76 . While, the respective values for the concentrate feed mixture $(100 \% \mathrm{TMR})$ were $67.53 \% \pm 0.59$ and $71.19 \% \pm 0.76$ for IVDMD and IVOMD, respectively. Differences were significant $(\mathrm{P}<0.01)$. It could be concluded that SBPT. $H$ was the most effective treatment in improving both IVDMD and IVOMD of sugar beet pulp. The improvement achieved was $8.70 \%$ for IVDMD and $8.64 \%$ for IVOMD than the untreated SBP. The best inclusion level of SBP T. H. in the TMR was $40 \%$ as the improvement achieved above the TMR alone was $4.81 \%$ for IVDMD and $3.47 \%$ for IVOMD.

Keywords: Sugar beet pulp, Trichoderma Harzianum, Saccharomyces cerevisiae, Urea and in-vitro technique.

\section{INTRODUCTION}

In-vitro technique to evaluate the availability of animal feed ingredients for feeding ruminant is already documented. It has the advantage of giving the result in few days, using few grams of the sample, a comparison among several ingredients could be made in a shortest time and it does not need sophisticated laboratory equipment's. Telly and terry technique (1963) was one of these worldwide used techniques. Sugar beet pulp (SBP the by-product of extracting sugar from beet) is produced nowadays in greater amounts. The area cultivated with sugar beet is growing up to replace sugar can as a source of sugar for human consumption. It is also to reduce water used for irrigation. It represents $6.5 \%$ of sugar beet crop according to Essi and Ulrike (2017). It is fibrous by product that contains $14.76 \%$ crude fiber, $52.41 \%$ neutral detergent fiber (NDF), 34.63\% acid detergent fiber. It is limited in crude protein content 


\section{Khaliel et al.}

(9.75\%), while its total digestible nutrients were in the range of 60-72\%, (Abd El-Fattah, 2013 and Greg Lardy 2016). Several methods were applied to increase the digestibility and the feeding value of Agroindustrial by products to diminish the gape of farm animal feeds (Ministry of Agriculture records 2016). Of these methods are supplementations of feed nutrients to cover the shortage being found in feed nutrient. Microbiological treatment to initially degrade the cell wall constituents of the product leading it more susceptible to ruminal microbial activity and fermentation is an alternative method for physical and chemical treatments (Mohamed and Hala, 2008, and Aly 2012). This study was conducted to examine the effect fungus plus media treatment on dry, organic matter, crude protein and crude fiber disappearance (EXP1). Urea supplementation (2\%) of the product to enrich its $\mathrm{N}$ content was included in different levels of feed mixture (EXP. 2). Several inclusion levels of SBP (0, 20, 40, 60, 80 and 100\%) treated with T. H. (SBPT.H.) in the total mixed ration were studied (EXP 3). This work is a preliminary study to evaluate the most effective method to improve the feeding value of SBP and the best inclusion level that would be applied on farm animals' nutrition (in-vivo) in the next work.

\section{MATERIALS AND METHODS}

The experimental work of the present study was carried out in the farm of Animal Production Department, Faculty of Agriculture, Minia University during the period of May 2014 to October 2014. This study was carried out in three experiments, to evaluate sugar beet pulp (SBP) as a feed ingredient. It was obtained from the Sugar and Integrated Industries Company in Abo korkas, Minia Governorate.

Experiment 1: In-vitro trial to study the dry matter (DM), organic matter $(\mathrm{OM})$, crude protein $(\mathrm{CP})$ and crude fiber (CF) disappearance (D) of SBP, SBP treated with media and SBP treated with Trichoderma Harzianum (T. H.) plus media.

Experiment 2: In-vitro trial to study the DMD and OMD of ureated SBP (2\%USBP) when represent different proportions $0,20,40,60,80$ and $100 \%$ of the concentrate feed mixture containing $20 \%$ wheat straw, performed as total mixed ration (TMR).

Experiment 3: In-vitro trial to study DMD and OMD of SBP treated fungi (Trichoderma Harzianum) plus media when represent different proportions (0, 20, 40, 60, 80 and 100\%) of TMR.

\section{Proximate analysis and fiber fractions of sugar beet pulp:}

Sugar beet pulp (SBP) was analyzed for (DM), (CP), ether extract (EE), (CF) and ash according to (A.O.A.C., 2006). Determinations of fiber fractions (neutral detergent fiber (NDF), acid detergent fiber (ADF), acid detergent lignin (ADL) of the tested rations were carried out according to Van Soest et al. (1991). Cellulose and hemicellulose (H-cellulose) values were calculated by difference.

Hemicellulose $=(\mathrm{NDF}-\mathrm{ADF})$, while Cellulose $=(\mathrm{ADF}-\mathrm{ADL})$.

\section{Microbiological treatment (fungal treatment):}

Fungal strain (Trichoderma harzianum) and Yeast strain (Saccharomyces Cerevisiae) were obtained from the Genetic Department and Microbiological Department, Faculty of Agriculture, Minia University. The microorganisms (fungi) and (yeast) were maintained on Potato dextrose agar (PDA) media. Four days old fungal culture in test tubes was used in treatment.

\section{Basal media composition:}

The basal media contain (2\% urea, $1.5 \%$ ammonium sulphate, $0.1 \%$ live dry yeast (Saccharomyces Cerevisiae) and $0.5 \%$ magnesium sulphate) as percent of SBP weight were dissolved in distilled water (twice the weight of SBP that would be treated.

\section{Citrate buffer 0.5 mole:}

21 grams of citric acid dissolved in one liter of distilled water and 29.4 grams of sodium citrate in another liter of distilled water. Mix 82 milliliters of the citric acid solution with 18 milliliters of the sodium citrate solution. Use one mole $(\mathrm{M})$ sodium hydroxide solution to adjust the $\mathrm{pH}$ of the mixture to 6.0. After that, make the final volume of the solution (citrate buffer) up to one liter with distilled water in a volumetric flask. 


\section{Treatment of SBP with Trichoderma harzianum:}

Use six 1-liter capacity flasks containing 50gm sugar beet pulp each. Moisten the SBP with basal media at solid (SBP): liquid ratio 1: 2 with basal media. Citrate buffer $0.5 \mathrm{M}$ was used to adjust the liquid phase $\mathrm{pH}$ values in the range of 5.0 to 6.0. The flasks were sterilized by autoclave at $121{ }^{\circ} \mathrm{C}$ for 20 minutes. After being cooled, flasks were inoculated with T. Harzianum (T.H.). The inoculum of (T.H.) was taken from slant culture in test tube. It was dipped in $10 \mathrm{ml}$ sterilized PDA and used to inoculate the experimental flasks at $10 \%$ (V/W) of SBP weight. While live dry yeast (Saccharomyces Cerevisiae) was inculcated at $0.1 \%$ of SBP $(50 \mathrm{gm})$ after three days from initial incubation with T.H in incubator at $30{ }^{\circ} \mathrm{C}$ for 7days, (Sherien, 2005 and Abd El-Maged, 2006).

\section{In Vitro procedure:}

In vitro technique was used to determine the DM and OM disappearance of SBP, USBP and SBP treated with fungi plus media, according to Tilley and Terry, (1963) technique after modification (Manual of laboratory techniques, University of Nebraska, Animal Production Department1986).

\section{Calculation:}

DM disappearance, $\left(\right.$ IVDMD \%) $=\frac{\text { [ IS W DM- (residualsw.(DM)- residualDM,of blank tub }]}{\text { ISW(DM) }} \times 100$

OM disappearance, $\left(\right.$ IVOMD \%) $=\frac{\left[\text { ISW.OM- }(\text { residualsw.(OM)- residualOM, of blank tubø }]_{X 100}\right.}{\text { ISW.OM }}$

ISW= initial sample weight. $\quad \mathrm{SW}=$ sample weight.

Table (1): Components of the total mixed ration mash (TMR) used in In Vitro experiments.

\begin{tabular}{ccccccc}
\hline Ingredients & $\begin{array}{c}\text { Wheat } \\
\text { bran }\end{array}$ & $\begin{array}{c}\text { Crushed } \\
\text { yellow corn }\end{array}$ & $\begin{array}{c}\text { Soybean } \\
\text { meal }\end{array}$ & $\begin{array}{c}\text { Wheat } \\
\text { straw }\end{array}$ & $\begin{array}{c}\text { Lime } \\
\text { stone }\end{array}$ & $\begin{array}{c}\text { Sodium } \\
\text { chloride }\end{array}$ \\
\hline$\%$ & 40 & 22 & 15 & 20 & 2 & 1 \\
\hline
\end{tabular}

\section{Statistical analysis of in vitro experiments:}

Experiment (1) Complete Randomized Design (CRD) was followed. Statistical analyses of the data were performed by application the least squares procedure described in SAS (2003) as follows:

$\mathrm{Y}_{\mathrm{ij}}=\mu+\mathrm{T}_{\mathrm{i}}+\mathrm{e}_{\mathrm{ij}} \quad$ Where, $\mathrm{Y}_{\mathrm{ij}}$ is the observation of In-Vitro (DM, OM, CP and CF) disappearance of different nutrients. $\mu=$ is the overall mean. $\mathrm{T}_{\mathrm{i}}=$ is the treatment effect where $\mathrm{i}=\mathrm{T} 1, \mathrm{~T} 2$ and T3 in the (invitro) trial SBP, SBP plus media and SBP T.H. plus media. $\mathrm{e}_{\mathrm{ij}}=$ the experimental error $\left(\mathrm{O}, \delta^{2}\right)$.

Experiment (2 and 3): Complete Randomized Design was followed. Statistical analyses of the data were performed by application the least squares procedure described in SAS (2003) as follows:

$\mathrm{Y}_{\mathrm{ij}}=\mu+\mathrm{T}_{\mathrm{i}}+\mathrm{E}_{\mathrm{ij}}$. Where, $\mathrm{Y}_{\mathrm{ij}}$ is the observation of In-vitro DM and/or OM disappearance of different treatments. $\mu=$ is the overall mean. $\mathrm{T}_{\mathrm{i}}=$ is the treatment effect where ${ }_{\mathrm{i}}=\mathrm{T} 1, \mathrm{~T} 2, \mathrm{~T} 3, \mathrm{~T} 4, \mathrm{~T} 5$ and T6 in the (in-vitro) trial where rations contained different proportions of USBP or SBP T.H. plus media. $\mathrm{e}_{\mathrm{ij}}=$ the experimental error $\left(\mathrm{O}, \delta^{2}\right)$.

\section{RESUITS AND DISCUSSION}

\section{Nutritional analysis of (TMR) and sugar beet pulp (SBP) used in this study:}

The nutritional analysis of total mixed ration $(\mathrm{TMR}=80 \%$ concentrate feed mixture $(\mathrm{CFM})+20 \%$ Wheat straw), air dried sugar beet pulp (ADSBP), SBP treated with media (SBP+M) and SBP treated Trichoderma Harzianum with media $(\mathrm{SBP}+\mathrm{M}+$ T.H) are elucidated in Table (2). Data indicated that $\mathrm{SBP}+\mathrm{M}+T$. $H$. contained the highest level of (CP) $20.30 \%$, the lowest content of (CF) $16.58 \%$, (NDF) $38.24 \%$, (ADF) $22.82 \%$, cellulose $18.33 \%$ and hemi-cellulose $15.42 \%$ as compared with SBP. SBP contains CP 9.16\%, CF 22.27\%, EE 1.06\%, NFE 63.18, NDF 48.11\%, ADF 26.94\%, (ADL) 3.49\%, 


\section{Khaliel et al.}

cellulose $23.45 \%$ and hemicellulose $21.16 \%$. Sugar beet pulp (SBP) has the highest levels of CF, NFE, $\mathrm{NDF}$ and hemicellulose compared with other treatments. While, SBP treated with media (SBP+M) contained CP 13.35\%, CF 18.40\%, EE 1.02\%, NFE 61.97\%, NDF 47.46\%, ADF 28.02\%, ADL 3.76\%, cellulose $24.25 \%$ and hemicellulose $19.44 \%$. The nutritional analysis of TMR showed that it's CP content was $15.30 \%, 18.30 \% \mathrm{CF}, 5.82 \%$ EE, 51.64\% NFE, 44.96\% NDF, 26.10\% ADF, 5.59\% ADL, $20.51 \%$ cellulose and $18.88 \%$ hemicellulose. Differences among treatments were significant $(\mathrm{P}<0.01)$ in each nutrient (Table, 2).

Table (2): Nutritional analysis of TMR, SBP, SBP+M, USBP and SBP+M+T.H.

\begin{tabular}{|c|c|c|c|c|c|c|}
\hline \multirow[t]{2}{*}{ Item } & \multicolumn{4}{|c|}{ Treatments } & \multirow{2}{*}{ \pm S.E } & \multirow{2}{*}{ Sig. } \\
\hline & TMR & SBP & $\mathrm{SBP}+\mathrm{M}$ & $\mathrm{SBP}+\mathrm{M}+T . H$ & & \\
\hline $\mathrm{DM}$ & $92.97^{\mathrm{a}}$ & $90.46^{b}$ & $88.22^{\mathrm{c}}$ & $88.62^{c}$ & 0.58 & $* *$ \\
\hline \multicolumn{7}{|l|}{ On DM basis } \\
\hline $\mathrm{OM}$ & $91.04^{\mathrm{b}}$ & $95.67^{\mathrm{a}}$ & $94.73^{\mathrm{a}}$ & $92.32^{\mathrm{b}}$ & 0.57 & $* *$ \\
\hline $\mathrm{CP}$ & $15.30^{\mathrm{b}}$ & $9.16^{\mathrm{d}}$ & $13.35^{\mathrm{c}}$ & $20.30^{\mathrm{a}}$ & 1.21 & $* *$ \\
\hline $\mathrm{CF}$ & $18.30^{\mathrm{b}}$ & $22.27^{\mathrm{a}}$ & $18.40^{\mathrm{b}}$ & $16.58^{\mathrm{c}}$ & 0.63 & $* *$ \\
\hline $\mathrm{EE}$ & $5.82^{\mathrm{a}}$ & $1.06^{\mathrm{b}}$ & $1.02^{\mathrm{b}}$ & $1.13^{\mathrm{b}}$ & 0.62 & $* *$ \\
\hline NFE & $51.64^{\mathrm{b}}$ & $63.18^{\mathrm{a}}$ & $61.97^{\mathrm{a}}$ & $54.31^{\mathrm{b}}$ & 1.49 & $* *$ \\
\hline NDF & $44.96^{\mathrm{b}}$ & $48.11^{\mathrm{a}}$ & $47.46^{\mathrm{a}}$ & $38.24^{\mathrm{c}}$ & 1.18 & $* *$ \\
\hline $\mathrm{ADF}$ & $26.10^{\mathrm{b}}$ & $26.94^{\mathrm{b}}$ & $28.02^{\mathrm{a}}$ & $22.82^{\mathrm{c}}$ & 0.59 & $* *$ \\
\hline ADL & $5.59^{\mathrm{a}}$ & $3.49^{c}$ & $3.76^{\mathrm{c}}$ & $4.49^{\mathrm{b}}$ & 0.24 & $* *$ \\
\hline Cellulose & $20.51^{\mathrm{b}}$ & $23.45^{\mathrm{a}}$ & $24.25^{\mathrm{a}}$ & $18.33^{\mathrm{c}}$ & 0.72 & $* *$ \\
\hline Hemiecellulose & $18.88^{\mathrm{c}}$ & $21.16^{\mathrm{b}}$ & $19.44^{\mathrm{c}}$ & $15.42^{\mathrm{d}}$ & 0.63 & $* *$ \\
\hline Ash & $8.96^{\mathrm{a}}$ & $4.66^{\mathrm{c}}$ & $5.27^{\mathrm{c}}$ & $7.68^{\mathrm{b}}$ & 0.53 & $* *$ \\
\hline
\end{tabular}

Treatment with fungus that secrete enzymes like as cellulases, hemicellulases, legninases that destruct the cell wall structure became nowadays an acceptable method to improve the feeding value of roughages, forages, farm and plant crop wastes (Sherien 2005, Abd El-Maged 2006, Aly et al., 2012 and Abd El-Fattah 2013). Treatment of such product with fungus includes preparation of media to activate and/or accelerate growth of fungus hyphae's and mycelium before incubation. Media used in this study contains urea, ammonium sulfate and active dry yeast (Sherien 2005 and Abd El-Maged 2006). These nitrogenous components increased the crude protein content of SBP plus media up to $13.35 \%$, while after incubation at room temperature the SBP, media and fungus growth $(\mathrm{SBP}+\mathrm{M}+T$. $H$.) increased the $\mathrm{CP}$ content up to $20.30 \%$ (Table, 2). This obvious increase in CP content could be explained in view of the reduction in $(\mathrm{CF}),(\mathrm{NFE}),(\mathrm{NDF})$ and $(\mathrm{ADF})$ concentrations; therefore the increase of $\mathrm{CP}$ in $\mathrm{SBP}+\mathrm{M}+T$. $H$. is of mathematical contention

\section{In Vitro dry matter and organic matter disappearance of sugar beet pulp (SBP), SBP+M and SBP+M+T. Harzianum:}

The In vitro dry matter disappearance (IVDMD) results of SBP, SBP plus media (SBP+M) and SBP treated with media and fungi $(\mathrm{SBP}+\mathrm{M}+T . H$. ) are displayed in Table (3). The values ranged from $58.85 \%$ to $63.97 \%$. The lowest value was for SBP, while the highest value was for $\mathrm{SBP}+\mathrm{M}+T$. $H$. The IVDMD of $\mathrm{SBP}+\mathrm{M}$ was $62.05 \%$. Differences among treatments were significant $(\mathrm{P}<0.01)$. The in-vitro organic matter (IVOMD) figures of $\mathrm{SBP}, \mathrm{SBP}+\mathrm{M}$ and $\mathrm{SBP}+\mathrm{M}+T$. $H$. were 62.87, 64.70 and $68.30 \%$, respectively. The in-vitro crude protein disappearance (IVCPD) of the tested treatments was $65.37,62.35$ and $51.34 \%$ respectively for $\mathrm{T} 1, \mathrm{~T} 2$ and $\mathrm{T} 3$. The highest value was $65.37 \%$ for SBP, while the lowest value was $51.34 \%$ for $\mathrm{SBP}+\mathrm{M}+T$. $H$. The In Vitro crude fiber disappearance (IVCFD) of untreated sugar beet pulp (T1) and SBP+M (T2) and SBP+M+T. H. (T3) were 34.98 and 36.45 and $41.24 \%$ for T1, T2 and T3, successively. The differences among treatments were significant (Table, 3). The IVDM, IVOM, IVCP and IVCF disappearances are indicators of these nutrients building-up and availability to be dissolved and digested by rumen microbes and pepsin enzyme. It is also accepted that if the cell wall constituents being less condensed, cracked, crushed or dissociated, the cell soluble will be available for microbial enzymes activity and fermentation. There is a lot of references that fungal treatment either 
Trichoderma sp., Aspargillus sp. and Phanerochaete Chrysosporium render the treated crop residue more digestible and having better feeding value (Mohamed et al., 2008, Ghoneem 2010, Abdel-Azim et al., 2011 and Aly et al., 2012). Results in Table (3) could be explained in this sense. The in-vitro DMD was increased by $8.7 \%$, the in-vitro OMD was increased by $8.6 \%$ and in-vitro CFD jumped up by $17.90 \%$ as SBP was treated with $T$. $H$. On the contrary the in-vitro CPD went backword 14.03 percentage unite that resemble depression of $21.46 \%$. This means that the protein content of SBP that have disappearance value of $65.37 \%$ was changed to a great extent to fungal crude protein that contain nucleic acids that is undigested or poorly digested (El-Badawi et al., 2003, Sherien 2005 and Saleh 2007).

Table (3): In Vitro dry matter, organic matter, crude protein and crude fiber disappearance for SBP, SBP + M and SBP + M+ T. $H$.

\begin{tabular}{|c|c|c|c|c|c|}
\hline \multirow[t]{2}{*}{ Item } & \multicolumn{3}{|c|}{ Treatments } & \multirow{2}{*}{ \pm S.E } & \multirow{2}{*}{ Sig. } \\
\hline & SBP (T1) & SBP+M (T2) & $\mathrm{SBP}+\mathrm{M}+T . H .(\mathrm{T} 3)$ & & \\
\hline IVDMD & $58.85^{\mathrm{c}}$ & $62.05^{\mathrm{b}}$ & $63.97^{\mathrm{a}}$ & 0.76 & $* *$ \\
\hline IVOMD & $62.87^{\mathrm{b}}$ & $64.70^{\mathrm{b}}$ & $68.30^{\mathrm{a}}$ & 0.80 & $* *$ \\
\hline IVCPD & $65.37^{\mathrm{a}}$ & $62.35^{\mathrm{a}}$ & $51.34^{\mathrm{b}}$ & 2.13 & $* *$ \\
\hline IVCFD & $34.98^{\mathrm{b}}$ & $36.45^{\mathrm{b}}$ & $41.24^{\mathrm{a}}$ & 0.95 & $* *$ \\
\hline
\end{tabular}

$\boldsymbol{S B P}+\boldsymbol{M}=$ sugar beet pulp plus media. $\mathbf{S B P + M + T .} \boldsymbol{H}$. = sugar beet pulp plus media with Trichoderma Harzianum. $\boldsymbol{I V D M D}=$ in-vitro dry matter disappearances. $\boldsymbol{I V O M D}=$ in-vitro organic matter disappearance $\mathbf{I V C P D}=$ in-vitro crude protein disappearance. $\mathbf{I V C F D}=$ in-vitro crude fiber disappearance. $(* *)=$ Significant different at $(P<0.01)$. Means in the same row with different superscripts $\boldsymbol{a}, \boldsymbol{b}$ and $\boldsymbol{c}$ is significantly different.

\section{In-vitro DM and OM disappearance of rations contained different levels of SBP plus $2 \%$ urea (2\%USBP):}

Data presented in Table (4) indicated that IVDMD of rations contained different proportions of SBP plus urea (2\%USBP) ranged from $62.81 \%$ to $69.64 \%$. The highest value was for ration contained $40 \%$ USBP while, the lowest value was for $100 \%$ USBP ration. The IVDMD values of rations contained 0 (control), 20, 60 and 80\% USBP were 67.53, 67.59, 68.68 and 64.30\%, respectively. Differences among treatments were significant $(\mathrm{P}<0.01)$ except the difference between 0 and $20 \%$ USBP, where it was not significant (Table 4). The IVOMD of rations contained different proportions USBP ranged from 64.36 to $72.68 \%$, the highest value was for $40 \%$ USBP ration, while the lowest value was for $100 \%$ USBP ration. The IVOMD of rations contain $0,20,60$ and 80\%USBP were $71.19,71.70,70.32$ and $65.84 \%$, respectively. Differences among treatments were significant $(\mathrm{P}<0.01)$ except the difference among 0, 20 and 40\% USBP, where it was not significant (Table 4). The third treatment (40\% USBP) achieved the best results in both dry and organic matter in-vitro disappearances.

Table (4): In vitro $\mathrm{DM}$ and $\mathrm{OM}$ disappearance of rations containing $(0,20,40,60,80$ and $100 \%$ USBP).

\begin{tabular}{|c|c|c|c|c|c|c|c|c|}
\hline Item & \multicolumn{6}{|c|}{ Treatments } & \multirow{3}{*}{$\pm \mathrm{SE}$} & \multirow{3}{*}{ Sig. } \\
\hline TMR\% & 100 & 80 & 60 & 40 & 20 & 0 & & \\
\hline USBP \% & 0 & 20 & 40 & 60 & 80 & 100 & & \\
\hline IVDMD & $67.53^{b}$ & $67.59^{b}$ & $69.64^{\mathrm{a}}$ & $68.68^{\mathrm{a}}$ & $64.30^{\mathrm{c}}$ & $62.81^{\mathrm{d}}$ & 0.59 & $* *$ \\
\hline IVOMD & $71.19^{\mathrm{ab}}$ & $71.70^{\mathrm{a}}$ & $72.68^{\mathrm{a}}$ & $70.32^{\mathrm{b}}$ & $65.84^{\mathrm{d}}$ & $64.36^{\mathrm{d}}$ & 0.75 & $* *$ \\
\hline
\end{tabular}

IVDMD = in-vitro dry matter disappearances. IVOMD =in vitro organic matter disappearances.

$T M R=$ the total mixed ration (concentrate feed mixture containing $20 \%$ wheat straw.

$(* *)=$ Significant different at $(P<0.01)$. Means in the same row with different superscripts $a, b, c, d$ and $e$ are significantly different.

\section{In-vitro DMD and OMD of rations contain different proportions of $S B P+M+T . H$ :}

Data presented in Table (5) indicated that IVDMD of rations contained different proportions of SBP treated with Trichoderma Harzianum (SBP+M+T. H) ranged from $64.27 \%$ to $71.68 \%$, the highest value 


\section{Khaliel et al.}

was for ration contained $40 \% \mathrm{SBP}+\mathrm{M}+T . H$. while, the lowest value was for $100 \% \mathrm{SBP}+\mathrm{M}+T . H$. ration. The IVDMD value of rations contained 0 (control), 20, 60 and $80 \mathrm{SBP}+\mathrm{M}+T$. H. \% was 68.39, 70.15, 67.71 , and $64.82 \%$, respectively. Differences among treatments were significant $(\mathrm{P}<0.01)$ except the difference between 80 and $100 \mathrm{SBP}+\mathrm{M}+$ T.H., where it was not significant. The IVOMD value of rations contained different proportions of SBPT. $H$. ranged, from 65.90 to $74.35 \%$, the highest value was for $40 \% \mathrm{SBP}+\mathrm{M}+T$. $H$. ration, while the lowest value was for $100 \% \mathrm{SBP}+\mathrm{M}+T$. $H$. ration. The IVOMD of rations contained $0,20,60$ and $80 \% \mathrm{SBP}+\mathrm{M}+T$. $H$. was $71.86,73.36,69.98$ and $66.51 \%$, respectively. Significant differences among treatments were found (Table 5). The third treatment $(40 \% \mathrm{SBP}+\mathrm{M}+T$. $H$.) achieved the best results in both dry and organic matter in In Vitro disappearances. The enhancement above $100 \%$ control rations was $4.81 \%$ for IVDMD and $3.47 \%$ for IVOMD. While, the improvement above $100 \% \mathrm{SBP}+\mathrm{M}+T$. $H$. was $11.53 \%$ for IVDMD and $12.82 \%$ for IVOMD. These results could be elucidated in view of the nutrient composition of the whole (concentrate feed mixture and USBP or $\mathrm{SBP}+\mathrm{M}+T . H$.$) . The differences among treatments were significant (\mathrm{P}<0.01)$ concerning IVDMD and IVOMD (Table, 5). The compatibility of these components to each other and the synergistic effect upon each other do its role. This is true as the IVDMD value of $100 \%$ control (concentrate feed mixture) was $68.39 \%$ while, the value of IVDMD for $40 \%$ inclusion level was $71.68 \%$ which is greater by $4.81 \%$. This means that $\mathrm{SBP}+\mathrm{M}+T$. $H$. add value to the CFM. In this way it is expected that $100 \% \mathrm{SBPT}$. H. should have greater value than the $40 \% \mathrm{SBP}+\mathrm{M}+T$. $H$. inclusion level. Unfortunately this is not the case as the value for $100 \% \mathrm{SBP}+\mathrm{M}+T$. $H$ was $64.27 \%$ which is $10.34 \%$ less than $40 \%$ inclusion level (Tables 4 and $5)$. Even-though the IVDMD or IVOMD values of SBP+M+T. $H$. was greater than USBP values, the variation could be explained as the $\mathrm{CF}, \mathrm{NDF}, \mathrm{ADF}$ and ADL (cell wall constituents) concentrations which were greater for USBP than $\mathrm{SBP}+\mathrm{M}+T$. $H$. (Table 2). It is generally well known that as the cell wall constituents were increased the digestibility values were decreased. In other words cell wall constituents' digestibility is lower than digestibility of cell soluble constituents, (McDonald et al., 2010).

Table (5): In-vitro DM and OM disappearance of ration containing $(0,20,40,60,80$ and $100 \%$ $\mathrm{SBP}+\mathrm{M}+\mathrm{T} . \mathrm{H}$.)

\begin{tabular}{|c|c|c|c|c|c|c|c|c|}
\hline Item & \multicolumn{6}{|c|}{ Treatments } & \multirow[b]{2}{*}{$\pm \mathrm{S} . \mathrm{E}$} & \multirow[b]{2}{*}{ Sig. } \\
\hline TMR\% & 100 & 80 & 60 & 40 & 20 & 0 & & \\
\hline $\mathrm{SBP}+\mathrm{M}+$ T.H. $\%$ & 0 & 20 & 40 & 60 & 80 & 100 & & \\
\hline IVDMD & $68.39^{c}$ & $70.15^{b}$ & $71.68^{\mathrm{a}}$ & $67.71^{c}$ & $64.82^{d}$ & $64.27^{\mathrm{d}}$ & 0.65 & $* *$ \\
\hline IVOMD & $71.86^{b}$ & $73.36^{\mathrm{ab}}$ & $74.35^{\mathrm{a}}$ & $69.98^{c}$ & $66.51^{\mathrm{d}}$ & $65.90^{\mathrm{d}}$ & 0.78 & $* *$ \\
\hline
\end{tabular}

$T M R=$ Total mixed ration (concentrate feed mixture containing $20 \%$ wheat straw). SBPT.H $=S B P+M+T . H$.

** Significant different at $(P<0.01)$. Means in the same row with different superscripts $a, b, c, d$ and $e$ are significantly different.

It could be concluded that SBP treated with fungus Trichoderma Harizanum was the most effective treatment in increasing dry matter, organic matter and crude fiber disappearances and its inclosing in the total mixed ration up to the level of $40 \%$ was the best level from nutritional point of view.

\section{REFERENCES}

Abd El-Fattah, H. H. A. (2013). Utilization of fibrolytic enzymes for improving sugar beet pulp digestibility as a component in dairy animal feed. Doctor of philosophy in agricultural science, faculty of agricultural, Ain Shams University.

Abd El-Maged, A. A. (2006). A study on the use of sugar beet pulp in the feed mixtures for ruminants. Ph. D. Sci. Thesis. Fac. of Agric. Ain-Shams Univ.

Abdel-Azim, Safa N., Mona A. Ahmed, F. Abo-Donia and H. Soliman (2011). Evaluation of fungal treatment of some agricultural residues. Egyptian Journal of Sheep \& Goat Sciences, Vol. 6 (2):1-13. 
AFRC, Agriculture and food research council (1993). Energy and protein requirements of ruminants. An advisory manual prepared by the AFRC Technical Committee on Responses to Nutrients. CAB international, Wallingford, UK. (P.P:91-106).

Ali, A. M. (2012). performance of growing ossimi lambs fed on rations containing fungal treated banana leaves with or without yeast addition. Egyptian J. Nutrition and feeds. 15(2): 255-260.

Allam, S. M., T. M. EL-Badawi, Hanan H. EL-Amary and Sheren H. Mohamed (2006). Improving Sugar beet pulp through biological treatments and its use in sheep ration. Egyptian J. Nutrition and Feeds. Vol, 9(2):235-247.

Al-Samaraae, W. H. and S. N. Alwaeli (2016). Effect of treated barley straw with Trichoderma Harzianum fungi in some productive characteristic. International Journal of Latest Research in Science and Technology. Volume 5, Issue 4: Page No.44-48, July - August 2016.

Al-Samarai, F. R. and A. H. A. Wathiq (2017). Effect of some environmental factors on hematological parameters in apparently healthy Iraqi awassi sheep. Journal of Entomology and Zoology Studies. 5(3): 1668-1671

Aly, A. M. (2012). Performance of growing ossimi lambs fed on rations containing fungal treated banana leaves with or without yeast addition. Egyptian J. nutrition and feeds. 15(2): 255-260.

AOAC (2006). Association of Official Analytical Chartists 15th ed. Official Methods of analysis. Washington D. C., MSA

Duncan, D. B. (1955. Multiple ranges and multiple F test. Biometrics, 11: 1-42.

El-Badawi, A.Y., Yacout, M. H. M. and Kamel, H. E. M. (2003). Effect of replacing corn with sugar beet pulp on ruminal degradation kinetics and utilization efficiency of rations by growing sheep. Egyptian J. nutrition and feeds. 6 special issues: 1349-1363.

Essi Evans and M. Ulrike (2017). Review: Sugar beets as a substitute for grain for lactating dairy cattle. Journal of Animal Science and Biotechnology. 8-25

Ghoneem, Wafaa M.A. (2010). Biological treatment of some agricultural and agroindustrial residues and their effect on performance of growing lambs. Doctor of philosophy in animal production. Faculty of Agriculture, Cairo University.

Greg Lardy (2016). Feeding sugar beet byproducts to cattle. Animal Sciences Department. Extension service, North Dakota state university. USA.

Mc Donald. P., Edwards, R. A. Greenhalgh, J. F. D. (2010). Animal Nutritional. Carbohydrates, Lignin, P. P 27. Fifth Edition,

Ministry of Agriculture, (2016). Ministry of agriculture and land Reclamation, Agricultural Statistics, Economic Affairs Sector, Arab Republic of Egypt .

Mohamed, M. I. and Abou-Zeina, Hala A. A. (2008). Effect of dietary supplementation with biologically treated SBP on performance and organs function in goat kits. American-Eurasian J. Agric.\& Environ. Sinc. 4 (4), 410 - 416.

Saleh, M. S. (2007). Predicating the nutritive value of different roughages used in ruminates feeding by some laboratory methods. J. Agric. Res. Kafr EL-Sheikh Univ. 33(1): 38-54.

SAS. (2003). Statistical Analysis system. SAS users Guide statistics. SAS institute inc; Cary, NC.

Sherien H. Mohamed. (2005): Biological treatment of sugar beet pulp and its use of sheep ration. M. Sci. Thesis Fac. of Agric. Cairo University.

Tilley, J. M. A. and Terry, R. A. (1963). A Two-Stage Technique for the In-vitro digestion of forage crops. J. Brit. Grassland Soc. 18:104.

Van Soest, P. J., Robertson, J. B. and Lewis, B. A. (1991). Methods of dietary fiber neutral detergent fiber and non-starch poly saccharine in relation to animal nutrition. J. Dairy Science. 74. P.P, 35833597. 


\section{Khaliel et al.}

دراسات معملية لتقييم لب بنجر السكر المضاف اليه 2\% يوريا او المعامل بالفطر كمكون غذائي فى المجترات

علي احمد بكر خليل, سمير توفيق تحمد فهمى, كحما الطاهر سلام , حسن عبد الله حسن ومصطقى عبد الهادي عبد الحكيم

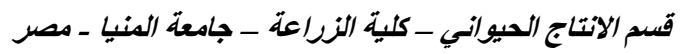

تدت هذه الدراسة فى معامل قسم الانتاج الحيو اني كلية الزراعة حيث استخدم لب بنجر السكر كناتج ثانوي من عمليات استخلاص السكر من بنجر السكر فى مصانع السكر بابوقرقاص بمحافظة المنيا.

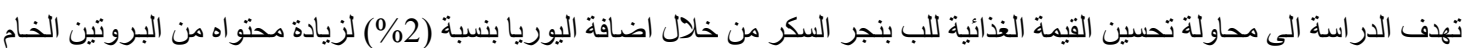

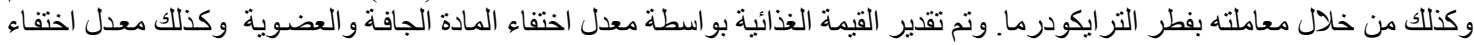

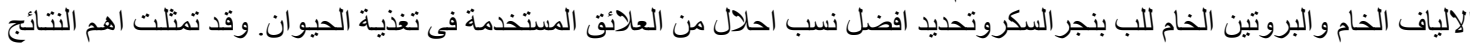
فيما يلى:

لــ أظهرت نتائج التحليل الغذائي لكلا من العليقة الكنترول ولب البنجر الغير معامل أو المعامل بالبيئة أو المعامل (باليئة و الفطر) تفوق

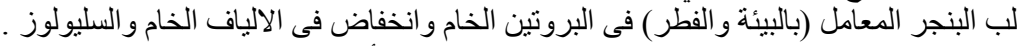

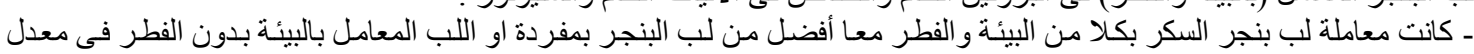

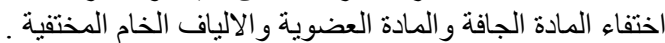
ـ كانت افضل نسبة احلال من العليقة الضـابطة بلب بنجر السكر المضاف اليه (2\%يوريا) عند نسبة 40\% لب بنجرمعامل باليورياو.

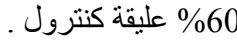
ـ كذلك كانت افضل نسبة احلال من العليقة الضابطة بلب بنجر السكر المعامل بالبيئة و الفطر هى 40\% لب بنجر معامل و 60\% عليقة كنترول

ويستخلص من هذه الدراسة انه يمكن استخدام لب بنجر السكر المعامل بالفطر والبيئة بنسبة (40\%) احلال من العليقة الكنترول فى تغذية

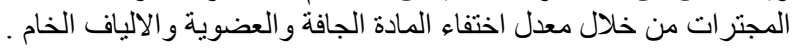

